DOI 10.5216/ia.v45i3.64980

\title{
EDUCAÇÃO E TRABALHO NAS PRISÕES DA PARAÍBA DO SÉCULO XIX
}

\author{
SUÊNYA DO NASCIMENTO COSTA \\ Jean Carlo de Carvalmo Costa \\ Universidade Federal da Paraíba (UFPB), João Pessoa, Paraíba, Brasil
}

\begin{abstract}
Resumo: Este artigo tem por objetivo abordar uma experiência de aulas primárias nas cadeias da Paraíba do século XIX. Criou-se, neste processo, uma cultura escolar específica marcada pela conexão entre a escolarização, trabalho e disciplina carcerária. Os métodos de análise utilizados, documental e bibliográfico, nos apresentam alguns aspectos da composição da cultura escolar prisional. Por exemplo, as normas e controle exercidos aos alunos/presos e professores, a aplicação de punições e os métodos de ensino. Assim, é possível concluir que as aulas ofereciam limitações curriculares, restringido às noções elementares de leitura, escrita e aritmética básica, buscando ofertar apenas uma instrução prática e elementar para o trabalho com algumas oficinas com intuito de formação dos sujeitos que realizassem uma ocupação considerada útil, mantendo, assim, o controle social e o status quo da sociedade da época.
\end{abstract}

Palavras-chave: Educação. Prisão. Trabalho. História da Educação.

\section{INTRODUÇÃO}

O objetivo deste artigo é analisar a instauração de aulas primárias no interior de cadeias da Província da Parahyba do Norte (nome do atual Estado da Paraíba durante o império brasileiro), como forma de regeneração por meio da instrução e trabalho no período imperial brasileiro. Instruir a grande parte da população era uma estratégia de formação de cidadãos úteis à pátria entre as que foram implementadas no final do século XIX, numa perspectiva de uma educação popular como apontam diversas produções historiográficas (CASTRO, 2011; CORREIA, 2011; RIZZINI \& SCHUELER, 2017; SOUSA, 2008; COSTA, 2017).

Escolas de primeiras letras foram instaladas em cadeias e prisões em todo o Império (SOUSA, 2008). E na província paraibana foi criada pelo vice-presidente de província, Antônio Alfredo da Gama e Mello, em 1882, no bojo do turbilhão de mudanças do ponto de vista educacional, econômico, jurídico, político, social e de mudança de regime, inerentes ao final do século XIX. (PARAHYBA DO NORTE, Província, 1882).

Para entender a dinâmica das escolas dentro das prisões da época, utilizamos como fontes o jornal "O Liberal Parahybano" nas edições de 1882, os relatórios presidenciais e dos chefes de polícia, legislação que criou as aulas nas cadeias da província paraibana e o regulamento para seu funcionamento. As fontes oficiais como 
relatórios e legislação, segundo Faria Filho (1998), possuem uma linguagem própria que obedece a aspectos como as estratégias discursivas e, por isso, é necessário pensá-las em suas múltiplas dimensões. No caso dos jornais enquanto fonte, concordamos com Morel e Barros $(2003$, p. 8 ) ao afirmarem que "a palavra impressa circulava e ajudava a delinear identidades culturais e políticas". Com isso, optamos por utilizar alguns jornais do período proposto no sentido de compreender neles as ideias produzidas pelo governo provincial no que diz respeito à instrução para uma determinada população: os presos.

No caso brasileiro, especificamente na Província da Parahyba do Norte, a segunda metade do século XIX foi caracterizada por uma certa "efervescência jornalística, onde os periódicos exerceram importante papel propagandístico e fiscalizador" (CURY; SOUZA, 2010, p. 1). Nos debruçamos no jornal "O Liberal Parahybano", órgão do governo que trouxe as questões relativas às aulas dentro das cadeias e o tipo de instrução destinada para esse público encarcerado, e no "Jornal da Parahyba", órgão de oposição ao governo provincial que teceu críticas ao modo em que a província se encontrava para receber as aulas nas prisões da província.

Assim, ao interpretar o texto jornalístico, levamos em consideração que essa fonte se traduz enquanto enunciado, visto que ele é concebido como instrumento que propõe a demarcação de formas de pensamento manifestadas como valores e modos de atuação em cada contexto. Por isso, a escolha das fontes utilizadas pretendeu demonstrar, dentro dos limites que cada tipo de documentação apresenta, as possibilidades de se considerar as práticas instrucionais ou educativas presentes nas organizações e instituições da época.

No caso das cadeias no século XIX, enquanto instituição, associando a educação ao trabalho, elas visaram a preparar a mão de obra dos presos para ser usada durante e após a sua reclusão, sendo o trabalho e a instrução oferecidos ali como regeneradores morais. Essa ideia em torno da necessidade intrínseca de instrução básica, conhecida como ensino das primeiras letras, adicionada a uma educação religiosa para os presos, era proferida pelos administradores das províncias brasileiras daquele período. Presidentes de províncias, chefes de polícia, ministro de justiça, enfim, todos eles defendiam as aulas nas cadeias, pois havia o entendimento de uma relação entre instrução e criminalidade (SOUSA, 2008).

Além do que, salvaguardando as especificidades do tipo de ensino que era ofertado para cada camada da população, observamos que, de modo geral, a oferta de instrução estava sintonizada com o pensamento em torno da modernidade, que enxergava na instrução o meio de alcançar o progresso e, no caso das aulas em cadeias, a construção de um homem novo, regenerado, que fosse útil à nação (SOUSA, 2008).

Assim, a instrução era encarada como forma de combater o crime e precaver a delinquência. Servia como prevenção da criminalidade. E no caso dessa instrução para quem já estava preso, a visão era de que haveria a recuperação do criminoso a partir de uma concepção de regeneração. Ao lado do trabalho (aprendendo um ofício que fosse útil), da instrução (com os rudimentos de leitura, escrita e aritmética básica) e a educação moral (vinda do ensino religioso ministrado nas aulas) seria possível, na 
COSTA, S. do N.; COSTA, J. C. de C.

concepção da época, um processo de regeneração e, com isso, a reinserção desses presos na sociedade.

Para tanto, empreender essas demandas como trabalho e instrução nas instituições prisionais requeriam que estas tivessem condições de abrigar tais atividades. No próximo tópico, apontamos como se deram os debates e as ideias sobre as reformas jurídicas no império brasileiro que visavam ao ideal de modernidade daquele período.

\section{EDUCAÇÃO E PRISÕES: EXIGÊNCIAS DO SÉCULO XIX E O IDEAL DE MODERNIDADE}

Com a independência do Brasil veio também a necessidade de construção de uma Constituição, e a nossa primeira carta magna foi outorgada em 1824, trazendo legislação referente às prisões. Além disso, a criação do Código Criminal em 1830 trouxe questões sobre as penas de prisão inspiradas nas ideias provenientes de outros países, sobretudo Estados Unidos e países da Europa, e que circulavam no império brasileiro numa perspectiva voltada para a "regeneração" dos presos (SLEMIAN, 2008; PARAHYBA DO NORTE, 1882).

Já durante a segunda metade do século XIX, havia o debate em torno das reformas jurídicas e o interesse de garantir aos estabelecimentos prisionais boas condições de higiene, seguindo os princípios de formação de um ideal de boa civilização e preconizando o que também já estava prescrito na Constituição de 1824, artigo 179. Isto é, o referido artigo da carta magna estabeleceu a garantia de que as cadeias deveriam ser "seguras, limpas e bem arejadas, havendo diversas casas para separação dos réus, conforme suas circunstancias e natureza de seus crimes." (BRASIL, 1824).

Antes disso, o que se tinha era o modelo colonial que, de modo geral, nas cadeias compunham salas fechadas para os presos ficarem, um cômodo onde eram realizados interrogatórios e aplicação de torturas e um outro espaço para encarceramento de quem cometeu crimes eclesiásticos ou até crime de traição contra o rei, denominado de crime de lesa-majestade. Porém, no Império, o encarceramento se tornou a principal punição aos criminosos, pondo um fim, ainda que de forma lenta e gradativa, ao período em que as punições eram públicas em forma de suplício.

A reestruturação prisional entre a Constituição e o Código Criminal, inspirados nos modelos europeus e estadunidenses, trouxe mudanças arquitetônicas e administrativas para as casas de prisão no século XIX (SLEMIAN, 2008). Desse modo, as casas de prisão, incluindo as do Brasil durante o século XIX, mas principalmente na segunda metade dos oitocentos, não eram mais vistos enquanto "lugar de passagem à espera da sentença final, mas com um papel de grande relevância para combater o crime e proporcionar condições para que os indivíduos pudessem se regenerar para o retorno à sociedade." (SANT'ANNA, 2007, p. 4-5).

$\mathrm{Na}$ prática, muitos desses aspectos e determinações do novo modelo internacional de um sistema penal não foram efetivados de imediato. Na Paraíba, por exemplo, as cadeias não estavam preparadas segundo o modelo desejado já nas últimas décadas do século XIX:

Esta província conta 26 delegacias, 98 districtos de subdelegacias. Tem algumas cadeias regulares, taes como da capital, CampinaGrande, Pombal, Mamanguape, Teixeira, Patos e Areia. Nas outras localidades servem de cadeia edifícios públicos e particulares, sem 
as necessárias condições. Nenhuma cadeia porém, nem mesmo a da capital, está em termos de prestar os serviços, que os criminalistas exigem de uma casa de prisão. (PARAHYBA DO NORTE, Província. 1882a, p. 5).

Como a privação da liberdade se tornou critério para punir, seguindo, nesse sentido, a circulação de ideias entre os diversos países no que se referia às reformulações penais, a pena de prisão com trabalho se tornou o método de correção moral dos criminosos no Brasil, sendo este o tipo de punição que mais se aplicou a partir do Código Criminal imperial (MAIA; NETO, 2011).

Havia assim, na concepção da época, a urgente necessidade de ter no Brasil um sistema penitenciário que pensasse as questões defendidas, como regeneração dos presos e o controle social dessa população considerada criminosa, e isso se daria pelo trabalho enquanto os sujeitos encontravam-se encarcerados. Vejamos no Código Criminal como deveria proceder a pena de prisão com trabalho:

Art. 46. A pena de prisão com trabalho, obrigará aos réos a occuparem-se diariamente no trabalho, que lhes fôr destinado dentro do recinto das prisões, na conformidade das sentenças, e dos regulamentos policiaes das mesmas prisões.

Art. 47. A pena de prisão simples obrigará aos réos a estarem reclusos nas prisões publicas pelo tempo marcado nas sentenças.

Art. 48. Estas penas de prisão serão cumpridas nas prisões publicas, que offerecerem maior commodidade, e segurança, e na maior proximidade, que fôr possivel, dos lugares dos delictos, devendo ser designadas pelos Juizes nas sentenças.

Quando porém fôr de prisão simples, que não exceda a seis mezes, cumprir-se-ha em qualquer prisão, que haja no lugar da residencia do réo, ou em algum outro proximo, devendo fazer-se na sentença a mesma designação.

Art. 49. Emquanto se não estabelecerem as prisões com as commodidades, e arranjos necessarios para o trabalho dos réos, as penas de prisão com trabalho serão substituidas pela de prisão simples, acrescentando-se em tal caso á esta mais a sexta parte do tempo, por que aquellas deveriam impôr-se. (BRASIL, 1830).

Elementos considerados essenciais para que a pena de prisão pudesse então atingir seus objetivos estavam atrelados ao funcionamento do estabelecimento, o tipo de trabalho, sua rotina e disciplina estabelecida. Cabia à força policial a incumbência de executar alguns dos principais aspectos práticos do funcionamento das prisões, a saber: a inspeção nos estabelecimentos, executar castigos disciplinares e elaborar formas de fornecimento da alimentação (ração) dos encarcerados.

Na Província da Parahyba do Norte, o regulamento da cadeia mostra que cabiam aos presos pagarem com o produto de seus trabalhos metade das despesas feitas com eles. No entanto, essa disposição era considerada letra morta, já que se alegava não haver estrutura para as oficinas, como relata o vice-presidente na citação a seguir:

Inter-Ação, Goiânia, v.46, n.1, p. 183-198, jan./mar. 2021. Disponível em: <http://dx.doi.org/10.5216/ia.v45i3.64980>. 
COSTA, S. do N.; COSTA, J. C. de C.

As nossas prisões não satisfazem bem a mais elementar das condições - a segurança - quanto mais as de trabalho, instrucção, moralidade e consequente regeneração dos infelizes presos. $\mathrm{O} d r$. Chefe de polícia tem feito quanto é possível n'este sentido, já instituindo aulas de primeiras letras, já montando oficinas, mas tudo isto incompleto porque o edifício não se presta para tão nobre fim. Esta questão deve merecer-vos o maior cuidado, por quanto é muito crescida a verba da despeza feita com os presos pobres. (PARAHYBA DO NORTE, Província. 1882a, p. 5).

Com isso, a compreensão de ter uma pena que fosse correcional e ao mesmo tempo útil à sociedade vigorava nesse período com a ideia de que

[...] o trabalho e a educação moral e religiosa eram as grandes regras para a reabilitação do criminoso, pois o trabalho o prepararia para a volta ao convívio social, livre dos males da ociosidade, e a religião e a orientação moral o afastariam de ideias tidas como perniciosas ao sujeito e à sociedade. (MAIA; NETO, 2011, p. 191).

Em muitos dos países europeus e nos Estados Unidos da América ocorreram proposições voltadas à criminalidade, a delinquência e ao caráter "reformador" e "regenerador" dos criminosos através do tripé: trabalho, educação e religião. Essas ideias chegaram ao Brasil através de um movimento penitenciário que surgia em diversos países. A circularidade dessas ideias se dava:

[...] a partir de visitas e inspeções aos estabelecimentos penitenciários de distintas nações, colocando em discussão os assuntos relacionados à execução das penas nos sistemas penitenciários da Europa e América. Mas também pela publicação de relatórios, livros, manuais e periódicos. (VASQUEZ, 2013, p. 14).

Com isso, o debate em torno das reformas das cadeias, que começou em cada país de maneira localizada, tomou proporção mundial, sobretudo na segunda metade do século XIX com o Congresso Internacional Penitenciário, sediado na Inglaterra em 1872 e na Itália em 1885. Além das Exposições Universais de Paris em 1867, de Viena no ano de 1873 e Filadélfia em 1876 (VASQUEZ, 2013).

A participação do Brasil nessas exposições universais evidenciava o interesse nos debates pela questão prisional e pode ter sido efetivada nesses eventos científicos através das trocas de informações, troca de relatórios, cartas e outros impressos. Por exemplo, em um dos relatos de viagem de D. Pedro II, observa-se o interesse do imperador em visitar as prisões do império e sugerir melhoramentos. Dessa forma, o país tentava projetar e fortalecer a imagem de nação civilizada diante dos países europeus e dos Estados Unidos sempre que participava dessas exposições universais (VASQUEZ, 2013).

Assim como nas questões jurídicas e carcerárias, no campo educacional esse debate da instrução enquanto forma de civilizar e de estimular o caráter regenerador também era constante nesse período. A instrução, desse modo, assumia uma perspectiva intimamente relacionada com a formação de um homem que fosse ordeiro 
e civilizado. Esse sujeito civilizado e instruído se torna o modelo de cidadão moderno e era função da escola formá-lo. Sobre a ideia de incorporar os códigos de civilidade, Carlota Boto (1996) afirma:

\begin{abstract}
Nessa preocupação com os códigos de civilidade e de virtude para os quais a educação deveria ser dirigida, havia uma tríplice finalidade em relação à matéria: bem-estar individual, da família e do Estado. Não há quem já nasça instruído ou formado: esse seria o argumento que sinalizava para a necessidade de universalização do processo pedagógico. (BOTO, 1996, p. 54).
\end{abstract}

Durante o império brasileiro, o projeto de nação que era pretendido estava atrelado ao papel desempenhado pela instrução enquanto mecanismo privilegiado para a escolarização do povo. Essa defesa de instrução para o povo era crescente nos discursos públicos, como bem ressaltou a professora Cynthia Veiga ao afirmar que "a aprendizagem da leitura, da escrita, das contas, bem como a frequência à escola se apresentava como fator condicional de edificação de uma nova sociedade" (VEIGA, 2008, p. 502).

A imprensa e as elites políticas e intelectuais contribuíram, durante o século XIX, para a veiculação desse discurso salvador. Instruir a população significava uma das emergências do Estado, fazendo-se cumprir a necessidade de expansão da instrução elementar (CASTRO, 2011).

No plano político e social, o pensamento do século XIX em formar um cidadão para ser útil à pátria, mas, principalmente, formar sujeitos capazes de realizar uma ocupação útil, impediria o surgimento de "criminosos" e "delinquentes", expressões comumente utilizadas nos documentos oficiais para se tratar de indivíduos que cometessem algum ato infracional (CASTRO, 2011).

O regulamento que criava as aulas nas cadeias da província paraibana apresentava a ideia de educação como regeneradora, como salvadora, assim como toda legislação que se refere à educação naquele período. Todavia, essa retórica consubstanciada nas leis não se configurava da mesma forma nas diferentes camadas sociais. Sérgio Adorno (1988) chama a atenção para essa diferenciação do ponto de vista legal e a sua aplicação no cotidiano da sociedade brasileira do XIX ao afirmar a necessidade do Estado ter um ordenamento jurídico legitimado através de uma lógica de igualdade, mas que na prática não encontrava eco que a sustentasse.

Dessa forma, o papel da instrução em relação à criminalidade fez com que o século XIX observasse a introdução de aulas de primeiras letras e de aritmética básica no interior das prisões, além de ensino religioso. Viu-se, por parte da elite, a necessidade de oferecer aos presos a instrução capaz de torná-los civilizados, ordeiros e úteis à nação. Nesse sentido, as cadeias se tornaram espécies de hospitais morais e a instrução e o trabalho oferecidos ali ocasionariam a reabilitação dessa população carcerária, como poderemos observar no tópico a seguir.

EDUCAÇÃO E TRABALHO: IDEÁRIOS DE “APERFEIÇOAMENTO MORAL” E “REGENERAÇÃO” 
COSTA, S. do N.; COSTA, J. C. de C.

Nessa linha de pensamento, em que a instrução era encarada como uma das formas de combater a delinquência, tanto como meio de prevenção nas estatísticas criminais como também um veículo de recuperação ou, para usar o termo dos gestores, de regeneração, a educação moral logo fez parte do discurso político paraibano. O então vice-presidente da província paraibana, Antônio Alfredo da Gama e Mello, aprovou provisoriamente o regulamento redigido pelo chefe de polícia Dr. Gonçalo Paes de Azevedo Faro, em 1882, instituindo aulas de primeiras letras e religião em algumas cadeias.

No relatório enviado à Assembleia Legislativa de 21 de maio de 1882, o então vice-presidente da província paraibana afirmava ter a intenção de dar instrução aos presos para atingir o rigor da pena ao sujeito encarcerado e erguer a função de regeneração:

\begin{abstract}
[...] promovi alguns melhoramentos materiaes e moraes em algumas das cadeias da Província e especialmente na da Capital, no intuito de suavizar a sorte dos infelizes, que néllas se acham reclusos. Entre eles sobresahe o da creação de escolas do ensino primário, que effectivamente foram estabelecidas em data de 8 do corrente mez, na Capital, e de 3 nas de Campina Grande, Areia e Pombal, dependendo estes actos de aprovação d'Ássembléa. Designei para reger a primeira, o professor do ensino primário do bairro-baixo desta Capital, Brasilino Pereira Lima Wanderley, mediante a gratificação mensal de $60 \$ 000$ rs. (PARAHYBA DO NORTE, Província. Relatório..., 1882a, p.4. Grifos nossos).
\end{abstract}

Em setembro de 1882, o jornal "O Liberal Parahybano" publicou o regulamento dessas aulas dentro das prisões. O documento, confeccionado pelo chefe de polícia, era composto de 17 artigos detalhando o funcionamento das aulas, os honorários dos professores, a composição do currículo, as práticas pedagógicas a serem seguidas, competências do professor, assim como as penas disciplinares para os alunos/presos. ( $O$ LIBERAL PARAHYBANO, 1882).

O regulamento trazia a figura de dois sujeitos imprescindíveis para essa configuração de ensino na cadeia: o capelão e o professor - cuja preferência era dada àquele que já atuava na escola primária. De acordo com o artigo $4^{\circ}$, cabia ao professor primário ensinar a ler, escrever, oferecer noções de gramática portuguesa e princípios elementares de aritmética. Quanto ao capelão, era responsável pelo catecismo e pela instrução moral e religiosa. Ambos eram nomeados pelo presidente de província sob proposta de indicação do chefe de polícia (O LIBERAL PARAHYBANO, 1882).

$E$ os alunos, quem eram? Conforme o regulamento publicado no jornal "O Liberal Parahybano" (1882), eram obrigados a frequentar a escola todos os presos que não soubessem ler e escrever, exceto os maiores de 60 anos de idade e os detidos correcionalmente. A legislação refere-se aos detidos correcionalmente como aqueles cujas passagens nas prisões se deram por crimes considerados leves, como de desordem pública, embriaguez, escravos recolhidos a pedido de seus senhores etc.

Dentre os presos mais adiantados e que fossem considerados com bom comportamento, o professor escolhia para formar decuriões com a finalidade de ajudar nos trabalhos escolares. Esses decuriões, em contrapartida, como pagamento desses 
serviços, podiam alcançar regalias concedidas pelos juízes das prisões (O LIBERAL PARAHYBANO, 1882).

A escola primária funcionava todos os dias úteis das 16 às 18 horas da tarde, com exceção das quintas-feiras, que eram destinadas à instrução religiosa ministrada pelo capelão. Os presos que soubessem ler e escrever e os maiores de 60 anos estavam isentos de frequentar as aulas. No entanto, eles teriam que assistir às aulas religiosas com o capelão. Antes de começar e ao terminar os trabalhos da escola, sob vigia do carcereiro, o professor e todos os alunos de pé entoavam hinos instituídos pelo chefe de polícia (O LIBERAL PARAHYBANO, 1882).

Destacamos que o Código Criminal de 1830, que estava em vigor no Império, determinava que era competência do chefe de polícia inspecionar as prisões da província, nomear e demitir carcereiros, vigiar e providenciar tudo que pertence à prevenção de crimes e manutenção da segurança das cadeias, à tranquilidade pública e encaminhar relatórios e regulamentos ao Ministro da Justiça e aos presidentes de província (BRASIL, 1830).

Cabia, ainda, ao chefe de polícia, receber dos professores uma espécie de registro dos alunos com as necessárias observações sobre o aproveitamento e conduta de cada um. E, além disso, segundo a legislação, a inspeção da escola era exercida por esse funcionário, que, por sua vez, poderia impor ao professor, quando omisso, a multa de dez a vinte mil réis (SLEMIAN, 2008).

Sobre o método de ensino, nem os jornais, nem os relatórios, nem o próprio regulamento explicita qual método deveria ser adotado nas aulas das prisões. No entanto, é possível deduzir, através das fontes, que a sala de aula comportava um grande número de alunos, pois o regulamento apresenta a prática de decúrias $(0$ LIBERAL PARAHYBANO, 1882).

Isto é, consideramos um seguimento de práticas referentes ao ensino mútuo, também conhecido como método Lancaster. $O$ método de ensino mútuo defendia, dentre outras questões, que o aluno considerado mais adiantado nas matérias (chamado decurião), deveria ensinar um grupo de 10 alunos (esse grupo era chamado de decúria), sob a supervisão do professor. Assim, nesse método, os alunos mais adiantados deveriam ajudar os professores na função do ensino (FARIA FILHO, 2007). O papel atribuído ao professor nas aulas em cadeias não era diferente do das escolas regulares para crianças. O caráter moralizador da função docente era explicitado no artigo 11 , parágrafo $3^{\circ}$ que designava ao docente

\footnotetext{
[...] promover por todos os meios a seu alcance a adiantamento dos alunos esforçando-se principalmente em incutir em seus ânimos os princípios de honra, patriotismo e práticas das virtudes christães. (O LIBERAL PARAHYBANO,1882, paginação irregular).
}

As atribuições destinadas ao ofício dos professores determinavam formas de disciplinar os presos/alunos, pois também era de competência do professor aplicar as penas disciplinares estabelecidas e levar ao conhecimento do chefe de polícia as necessidades de maior castigo ao aluno que resistisse à punição. Sobre as penas disciplinares, variavam desde a má nota, repreensão na aula ou, de modo particular, 
reclusão na solitária por tempo nunca excedente a 24 horas, até o castigo mais severo por determinação do chefe de polícia, como já foi mencionado, quando no caso do professor reclamar.

Receberia essas punições o aluno que faltasse com o respeito ao professor e ao capelão, o que usasse palavras, gestos ou sinais considerados insultuosos ou indecentes na aula, aquele que se mostrasse desatento às lições ou perturbasse os trabalhos da sala, o que se apresentasse com qualquer arma, o que saísse do seu lugar sem licença do professor e o que não tivesse o necessário cuidado na guarda e conservação de seus livros ou qualquer outro objeto concernente ao ensino, assim como estragasse e subtraísse os de seus companheiros.

Diante disso, nota-se a ação normatizadora pautada no discurso civilizatório defendido na legislação e reproduzido nos jornais. Assim, todos os aspectos da vida escolar passaram a ser regulamentados nos mínimos detalhes e nas prisões não seria diferente, determinando normas para os alunos e professores, para a frequência, fiscalização e distribuição de funções, de prêmios e aplicação de punições.

Não podemos afirmar que no Brasil imperial existia um sistema penitenciário que regulasse, a partir de legislação, todas as cadeias do Brasil de forma universalizada, porém as reformas dentro delas eram respaldadas e constavam nos relatórios de ministros e secretários de Estado dos Negócios da Justiça para a Assembleia Geral Legislativa, como pudemos observar nos documentos, assim como nos relatórios de presidentes de província.

Visando ao patamar civilizado, como em outras nações, era inaceitável, à época, que o Brasil apresentasse sujeitos sem dominar os requisitos mínimos do ler, escrever e contar, conhecimentos que eram essenciais ao progresso, modernização e civilização do país, possibilitando que os presos se tornassem sujeitos considerados regenerados. Nesse sentido, o discurso das lideranças políticas, como no caso do vice-presidente da província paraibana, Gama e Mello, pertencente ao partido liberal, apontava esse caminho em que a instrução, juntamente com o trabalho, eram necessários para moralizar os presos a fim de libertá-los de suas transgressões causadas pela falta de luzes do conhecimento (O LIBERAL PARAHYBANO, 1882).

Na edição do periódico "O Liberal Parahybano", Gama e Mello via os presos como "victmas de sua ignorância e de paixões não temperadas por uma educação regular que se precipitaram no despenhadeiro dos crimes." (O LIBERAL PARAHYBANO, 1882). Para o vice-presidente Gama e Mello,

o fim principal da pena é a correção e emenda do culpado, para que se obtenha a sua reabilitação, ficando o exemplo como um incentivo para que outros não caiam na mesma culpa, assegurandose por esta forma a ordem social. Mas não se atinge a esse grande resultado somente porque se encarceram os transgressores das leis: entretanto por uma vida de ensino e de trabalho exercitando no centro das prisões se poderá melhorar a condição de tantas victimas da perversão de costumes e muitas vezes da precipitação de um momento desgraçado. A instituição de penitenciarias segundo aconselham as luzes adiantadas do século em que vemos é uma necessidade palpitante de que decorrem sazonados fructos, já no intuito da obtenção do fim da pena, e já no de minorar-se o 
improfícuo dispêndio que se faz com um cem número de condenados (O LIBERAL PARAHYBANO, 1882).

As aulas nas cadeias passaram a fazer parte do dia a dia prisional no século XIX. Elas tinham por característica as limitações impostas à instrução dos presos restrita às noções elementares de leitura, escrita e aritmética básica. Isto é, buscavam ofertar apenas uma instrução prática e elementar para o trabalho como estratégia de controle do tempo do preso no próprio cotidiano da prisão.

Esse tempo se dividia entre a instrução, educação profissional e o descanso útil preenchido pela educação moral, efetivada pela religião através das aulas de catecismo, cujo ensino era ministrado pelos capelães das cadeias. Segundo o regulamento, cabia ao carcereiro encaminhar os presos para o local onde funcionaria a sala de aula, de modo que todos estivessem ali na hora devida, e depois retorná-los as suas celas. Pensando nessa formação elementar para o trabalho dentro do controle de tempo estabelecido nas prisões, Gama e Mello afirmava que o trabalho era:

[...] uma grande virtude que acorda no coração do homem sentimentos, que pareciam dormitar até o momento da perpetração do delicto. [...] Não sendo porém o trabalho o único móvel capaz de obter o aperfeiçoamento do ser moral, compreendi, que elle devia ser amenizado pelo ensino e aprendizagem moral e religiosa a par do ensino de leitura aos presos analfabetos $(O$ LIBERAL PARAHYBANO, 1882).

Gama e Mello instituiu oficinas de trabalho obtendo a compra de ferramenta necessária para as práticas de carpintaria e formação de pedreiros. O que chama nossa atenção é o fato de que os próprios presos foram designados para reformar um espaço dentro da prisão, conforme foi publicado no "O Liberal Parahybano":

[...]conseguindo levantar no átrio da prisão um telheiro com a precisa capacidade para a tenda de carpina e marceneiro, em cuja mão de obra foram empregados os mesmos presos, dispendendose da quantia de cem mil reis, que foi por V. Exc. autorizada, apenas a de 80 mil reis com matéria prima e dez mil reis que mandei dar de gratificação aos presos que se ocuparam naquele trabalho $(0$ LIBERAL PARAHYBANO, 1882).

Dessa forma, o trabalho realizado pelos prisioneiros, como até hoje o é, serve como instrumento por meio do qual é possível distinguir o preso considerado "bom" daquele considerado "indomável" ou "irrecuperável". Dessa forma, é concedido a esses sujeitos um capital simbólico do qual será, de certa forma, beneficiado no seio das relações de sociabilidade com seus pares e até com seus superiores (CHIES, 2006).

A ideia do "bom homem" era atrelada aos sujeitos que trabalhavam e que tinham um ofício e ocupação. Do contrário, esses sujeitos poderiam ser confundidos ou considerados como foras da lei, vadios, vagabundos, termos incorporados no discurso policial ao se referir aos presos. O trabalho nas cadeias, de certo modo, também 
COSTA, S. do N.; COSTA, J. C. de C.

contribuiu para que os encarcerados pudessem inserir os ganhos oriundos de seus trabalhos para ajudar nas suas próprias despesas, além de ensinar o ofício a outros detentos. Sem contar que, ao cumprirem suas penas, poderiam tentar viver do ofício aprendido nas cadeias (PARAHYBA DO NORTE, 1882b). No relatório do chefe de polícia, por exemplo, há o registro de alguns dos trabalhos executados pelos presos para fins de fabricação de utensílios e mobília da própria prisão, ressaltando como o encarcermento com trabalho se tornava proveitoso para os cofres da província:

\begin{abstract}
Os presos carpinas e marceneiros fizeram toda mobília da escola constante de bancos, mesas e escarradeiras de madeira. Bem como 20 camas para enfermaria, concorrendo a província apenas com a matéria prima. Na officina de esteiras e cestas de palha também fizeram os presos 20 esteiras para a enfermaria. Sendo conveniente montadas as oficinas da cadeia muita economia fará a província e se aliviará de parte das despesas que faz com alimentação e vestuário dos presos pobres (PARAHYBA DO NORTE, relatório..., 1882b, p. 8).
\end{abstract}

É possível constatar, no discurso do chefe de polícia, o interesse na mão de obra trabalhadora dos presos em prol da economia financeira que a província paraibana poderia obter por trás de uma proposta dita regeneradora através do trabalho e do cidadão útil. O trabalho nas cadeias acabava visando a obter lucros ou diminuir os gastos com a complementação para os parcos orçamentos provinciais. Assim, desonerando os cofres públicos, livrava a província de gastar com determinados produtos que iriam beneficiar os presos, já que eles próprios produziam para si e para a cadeia os utensílios necessários para a manutenção dela (PARAHYBA DO NORTE, 1882b).

É importante ressaltar que os presos não foram passivos a algumas das situações de precariedade dessas cadeias. Os sujeitos ali encarcerados reclamaram por várias vezes da falta de repasse da verba para compra da alimentação fornecida.

\footnotetext{
Para evitar repetidas queixas dos presos contra alguns agentes do fisco e fornecedores do interior da província, deliberei que o fornecimento das diárias fosse em dinheiro, effectuando o pagamento de 10 em 10 dias pelo collector com assistência do Delegado Commandante do destacamento e do Promotor Publico da Comarca. Recebendo, porém, reclamação dos presos das cadeias de Pombal e do Brejo de Areia para que se lhes pagasse nas vésperas das feiras, entendi-me diretamente com o digno Inspetor do Thesouro Provincial, que logo providenciou nesse sentido. [...]encarreguei-lhe de fiscalizar a distribuição das rações dos presos pobres; e desde logo cessaram as constantes reclamações d'aquelles infelizes, que além do encarceramento eram fintados em suas parcas rações! (PARAHYBA DO NORTE, 1882b, p. 5).
}

Dessa forma, podemos perceber que os presos não aceitaram as condições a que eram submetidos e diante do descaso questionaram seus direitos e melhores condições de segurança, espaço e salubridade, conforme garantiam o Código Criminal e a própria Constituição. Fazendo uma reconstrução de horizontes interpretativos das fontes, constatamos esses sujeitos partícipes, ou seja, há a experiência individual e 
coletiva dos personagens que povoam o mundo da prisão ao observarmos a existência de petições às autoridades.

Por fim, constatamos que o discurso penitenciário incluía o trabalho, a aprendizagem de um ofício através de oficinas, a moral católica pela catequese, uma instrução elementar, chamada no século XIX de primeiras letras. Além disso, em todas essas categorias presentes é notório o caráter moralizador e civilizatório da instrução e do trabalho para a população carcerária na segunda metade dos oitocentos brasileiro.

\section{CONSIDERAÇÕES FINAIS}

No império brasileiro, a educação ocupou destaque nos debates políticos e jornalísticos ressaltando seu caráter moralizador e civilizatório na construção do Estado Nacional. O projeto de nação que se pretendia tinha amparo na legislação como parte integrante das estratégias de formação de cidadãos que fossem úteis à nação e as aulas nas cadeias seguiam essa orientação, fazendo parte de um esforço civilizatório das elites políticas. A pena de prisão com trabalho, com a instrução elementar e a criação de oficinas, foi realizada em prol de um discurso considerado regenerador, mostrando, assim, a interlocução entre instrução, trabalho, educação moral e o controle social, que eram, por sua vez, pressupostos defendidos no período. Verificamos que em vários momentos o trabalho do preso, através das oficinas criadas, perdia o caráter correcional, no sentido de recuperar e civilizar aqueles sujeitos, quando ganhava uma face econômica, complementando o orçamento provincial e eximindo o estado de sua responsabilidade com os presos.

A documentação referente às aulas nas cadeias é tímida em comparação ao que trazem os documentos sobre outras demandas de atividades, de organização e funcionamento carcerário. Os relatórios raramente mencionam aulas na cadeia ou informação relativas aos presos que frequentaram essas escolas. Mesmo assim, foi possível constatar que a preocupação em torno da estatística criminal não ficava apenas na prevenção aos crimes por meio da instrução. Essa preocupação se estendia às formas ditas como regeneração por meio da instrução e da moral para aqueles que cometeram delitos e se encontravam encarcerados. A documentação mostrou que, apesar das várias afirmações, tanto dos jornais quanto dos administradores pelos relatórios, reafirmando a necessidade de dotar os presos com a instrução, o trabalho e a moralidade ficou perceptível que as aulas nas cadeias ficaram por muitas vezes prejudicadas em razão dos inúmeros problemas enfrentados.

Desde a falta de salubridade em relação ao exigido pelos modelos internacionalmente propostos, passando pela dificuldade financeira, cujo discurso da elite política perpassa todo império no que tange à instrução, nas cadeias ou não, os problemas enfrentados para o funcionamento das aulas resultaram na ausência de uma política prisional que sustentasse os inúmeros e, sempre entusiasmados, discursos de valorização do trabalho e instrução como elementos de regeneração do criminoso. As experiências laborais das prisões na província paraibana demonstram que o discurso em torno da recuperação do preso criminoso, no momento em que partia para a prática, 
COSTA, S. do N.; COSTA, J. C. de C.

ficava em segundo plano nos interesses das autoridades diante do orçamento provincial.

Por fim, percebemos nas aulas instauradas nas cadeias paraibanas o teor disciplinar, o controle social por meio das regras, o currículo moralizador e a prática do trabalho para fins de uma mão de obra que fosse útil à nação, livrando o país dos "criminosos e vadios". Embora, ao averiguarmos que no plano das práticas pouco se adiantou na implantação dessas aulas, de modo que houvesse nela uma permanência ao longo das administrações da província, o debate das ideias foi, então, mantido durante todo o século XIX, inclusive em outras várias províncias brasileiras.

Artigo recebido em: 13/08/2020

Aprovado para publicação em: 18/11/2020

\section{EDUCATION AND WORK IN THE PRISONS PARAÍBA'S OF THE $19^{\text {TH }}$ CENTURY}

ABSTRACT: This article aims to address an experience of primary classes in the nineteenth-century Paraíba prisons. In this process, a specific school culture was created marked by the connection between schooling, work and prison discipline. The documentary and bibliographic analysis method used presents us with some aspects of the composition of prison school culture. For example, the rules and control exercised on students / prisoners and teachers, application of punishments and teaching methods. Thus, it is possible to conclude that the classes offered curricular limitations, restricted to the elementary notions of reading, writing and basic arithmetic, seeking to offer only a practical and elementary instruction for working with some workshops to form subjects capable of carrying out a useful occupation and maintaining, thus, social control and the status quo of society at the time.

KEYWORDS: Education. Prisons. Work. History of Education.

\section{EDUCACIÓN Y TRABAJO EN LA PRISIÓN DE PARAÍBA DEL SIGLO XIX}

RESUMEN: Este artículo tiene como objetivo abordar una experiencia de clases primarias en las cárceles de Paraíba del siglo XIX. En este proceso, se creó una cultura escolar específica marcada por la conexión entre la escuela, el trabajo y la disciplina carcelaria. El método de análisis documental y bibliográfico utilizado nos presenta algunos aspectos de la composición de la cultura escolar carcelaria. Por ejemplo, las reglas y el control que se ejerce sobre estudiantes / presos y profesores, aplicación de castigos y métodos de enseñanza. Así, es posible concluir que las clases ofrecieron limitaciones curriculares, restringidas a las nociones elementales de lectura, escritura y aritmética básica, buscando ofrecer únicamente instrucción práctica y elemental para trabajar con algunos talleres para formar sujetos capaces de realizar una ocupación útil y mantener, por lo tanto, el control social y el status quo de la sociedad en ese momento.

PALABRAS CLAVE: Educación. Cadenas. Trabajo. Historia de la Educación. 


\section{REFERÊNCIAS}

ADORNO, S. Os aprendizes do poder: o bacharelismo liberal na política brasileira. Rio de Janeiro: Paz e Terra, 1988.

BRASIL. Constituição Política do Imperio do Brazil. Rio de Janeiro, 1824. Disponível em: http://www.planalto.gov.br/ccivil_03/Constituicao/Constituicao24.htm. Acesso em: 4 mar. 2020.

BRASIL. Lei de 16 de dezembro de 1830. Código Criminal do Império do Brazil. Disponível em: http://www.planalto.gov.br/ccivil_03/leis/lim/lim-16-12-1830.htm. Acesso em: 4 mar. 2020.

BOTO, C. A Escola do Homem Novo: entre o lluminismo e a Revolução Francesa. São Paulo: UNESP, 1996.

CASTRO, C. A. Ordem, Trabalho e pobreza: as representações das casas dos Educandos Artífices no Brasil Império. In: CURY, C. E; ROCHA, S. P. da. (Orgs.) Culturas e Sociabilidades no Oitocentos: possibilidades de pesquisa. João Pessoa, PB, Editora Universitária UFPB, 2011. p. 47 - 64.

CHIES, L. A. B. A capitalização do tempo social na prisão: a remição no contexto das lutas de temporalização na pena privativa de liberdade. 2006. Tese (doutorado em Sociologia) - Universidade Federal do Rio Grande do Sul: Porto Alegre, 2006.

CORREIA, M. da S. A educação popular no Brasil império: as primeiras iniciativas de escolas noturnas em Alagoas (1870-1889). 2011. Dissertação. (Mestrado em educação) Universidade Federal de Alagoas, Maceió, 2011.

COSTA, S. do N. As ideias educacionais e políticas de Silvino Elvídio Carneiro da Cunha na província da Parahyba do Norte (1874 - 1876). 2017. Dissertação (Mestrado em educação) - Universidade Federal da Paraíba, João Pessoa, 2017.

CURY, C. E.; SOUZA, T. O. de. Os jornais paraibanos do século XIX como fonte para a História da Educação (1858 - 1889). VII Congresso Luso-Brasileiro de História da educação. São $2010 . \quad$ Luis, Disponível em: http://www.carlamaryoliveira.pro.br/gheno/PDF/Claudia_Cury_Thiago_Souza.pdf. Acesso em: 15 dez. 2019.

FARIA FILHO, L. M. de. A legislação escolar como fonte para a História da Educação: uma tentativa de interpretação. In: FARIA FILHO (Org.). Educação, modernidade e 
COSTA, S. do N.; COSTA, J. C. de C.

civilização: fontes e perspectivas de análises para a história da educação oitocentista. Belo Horizonte: Autêntica, 1998.

FARIA FILHO, L. M. de. Instrução elementar no século XIX. In:LOPES, E. M. T; FARIA FILHO, L. M. de; VEIGA, C. G. 500 anos de educação no Brasil. $3^{a}$ edição. Belo Horizonte: Autêntica, 2007. p. 135 - 150.

MAIA, C. N.; NETO, F de S. C. de A. O trabalho prisional na casa de detenção do Recife no século XIX, Passagens Revista Internacional de História política e Cultura Jurídica, Rio de Janeiro, vol. 3, n. 2, maio - agosto, 2011, p. 187 - 202. Disponível em: https://www.redalyc.org/pdf/3373/337327177003.pdf. Acesso em: 22 jun. 2019.

MOREL, M.; BARROS, M. M. Palavra, imagem e poder. O surgimento da imprensa no Brasil do século XIX. Rio de Janeiro: DP\&A, 2003.

O LIBERAL PARAHYBANO, Parahyba do Norte. Edição 00132. 12 de junho de 1882. n.p. Disponível em: http://memoria.bn.br/DocReader/DocReader.aspx?bib=704989\&PagFis=190\&Pesq=cad eas. Acesso em: 12 dez. 2019.

PARAHYBA DO NORTE, Província. Relatório Provincial. Relatório com que o exm. Sr. 1० vice-presidente dr. Antônio Alfredo da Gama e Mello passou a administração desta província ao sr. Exm. Sr. Manoel Ventura de Barros Leite Sampaio no dia 21 de maio de 1882. Disponível em: http://brazil.crl.edu/bsd/bsd/u521/000004.html. Acesso em: 12 dez. 2019.

PARAHYBA DO NORTE, Província. Relatório Provincial. Relatório apresentado a assembleia legislativa provincial da Parahyba do norte pelo presidente exm sr. Dr. Manoel Ventura de Barros Leite Sampaio, em 4 de outubro de 1882. 1882a. Disponível em: $\quad$ http://ddsnext.crl.edu/titles $/ 178 \# ? \mathrm{c}=0 \& \mathrm{~m}=80 \& \mathrm{~s}=0 \& \mathrm{cv}=5 \& \mathrm{r}=0 \& \mathrm{xy} w \mathrm{wh}=-1168 \% 2 \mathrm{C}-$ 49\%2C4015\%2C2832. Acesso em: 24 fev. 2020.

PARAHYBA DO NORTE, Província da. Relatório do chefe de polícia, 1882b, Disponível em: $\quad$ http://ddsnext.crl.edu/titles $/ 178 \# ? c=0 \& m=80 \& s=0 \& c v=5 \& r=0 \& x y w h=-210 \% 2 C-$ 208\%2C2098\%2C3147. Acesso em: 22 fev. 2020.

RIZZINI, I. \& SCHUELER, A. F. M. de. Trabalho e escolarização urbana: o curso noturno para jovens e adultos trabalhadores na Escola Municipal de São Sebastião, Rio de Janeiro (1872-1893). Revista Brasileira De História Da Educação, Maringá, v.17, n.1[44]), p. 89 115, 2017. Disponível em: http://periodicos.uem.br/ojs/index.php/rbhe/issue/view/1457. Acesso em 27 fev. 2020.

SANT'ANNA, M. A. Os espaços das prisões no Rio de Janeiro do século XIX. Anais das Jornadas de 2007. Programa de pós-graduação em História Social da UFRJ. Rio de Janeiro 2007.

Disponível em: https://revistadiscenteppghis.files.wordpress.com/2009/05/marilene-antunes-osespacos-das-prisoes-no-rio-de-janeiro-do-seculo-xix.pdf. Acesso em: 27 dez. 2019. 
SLEMIAN, A. À nação independente, um novo ordenamento jurídico: a criação dos códigos Criminal e do Processo Penal na primeira década do Império do Brasil. In: RIBEIRO, G. S. (Org.). Brasileiros e cidadãos. Modernidade Política (1822 - 1930). São Paulo: Alameda, 2008, p. 175 - 206.

SOUSA, I. C. J. de. Educar para a regeneração: a escola elementar da casa de prisão da Bahia-1871 a 1890. Anais. V Congresso Brasileiro de história da Educação: Aracaju. 2008. Disponível em: http://www.sbhe.org.br/novo/congressos/cbhe5/. Acesso em: 16 jul. 2019.

VASQUEZ, E. L. Ciência Penitenciária no Brasil Império: disciplinar para construir a imagem de nação civilizada. 2013. Tese (doutorado em História da ciência) - Pontifícia Universidade Católica de São Paulo, São Paulo, 2013.

VEIGA, C. G. Escola pública para os negros e os pobres no Brasil: invenção imperial. Revista Brasileira de Educação, Rio de Janeiro, v.13, n.39, 2008, p. 502 - 516.

SuÊnya do Nascimento Costa: Doutoranda no Programa de Pós-Graduação em Educação pela Universidade Federal da Paraíba (PPGE-UFPB). Mestra em Educação (PPGE-UFPB). Graduação em Pedagogia (UFPB). Especialista em Psicopedagogia e em História da Paraíba. Integra no Diretório do CNPq o HISTED-BR (Grupo de Estudos e Pesquisas História, Sociedade e Educação no Brasil), o GHENO (Grupo de Pesquisa História da Educação no Nordeste Oitocentista), na UFPB. É membro da Sociedade Brasileira de História da Educação (SBHE).

Orcid: http://orcid.org/0000-0002-0148-978X

E-mail:suenyacosta@outlook.com

Jean Carlo de Carvalho Costa: Doutor em Sociologia pela Universidade Federal de Pernambuco. Pós-doutorado no Instituto de Educação da Universidade de Lisboa. Professor e pesquisador da Universidade Federal da Paraíba (UFPB), no Programa de Pós-Graduação em Educação e no Departamento de Fundamentação da Educação. Integra no Diretório do CNPq o HISTED-BR (Grupo de Estudos e Pesquisas História, Sociedade e Educação no Brasil), o GHENO (Grupo de Pesquisa História da Educação no Nordeste Oitocentista) na UFPB e o Grupo História das Instituições e dos Intelectuais da Educação no Brasil (PUC-SP). Membro da Sociedade Brasileira de História da Educação (SBHE). Atua na docência superior nas áreas de Sociologia da Educação e de História da Educação, desenvolvendo pesquisas sobre História Intelectual e dos Intelectuais, História Conceitual, Teoria e História da Educação.

Orcid: http://orcid.org/0000-0002-6930-8607

E-mail: jeanccosta@yahoo.com.br

Este periódico utiliza a licença Creative Commons Attribution 3.0, para periódicos de acesso aberto (Open Archives Iniciative - OAI). 